\title{
Dual-Class Shares, External Financing Needs, and Firm Performance
}

\author{
Stephan Nüesch*
}

November 12, 2012

\begin{abstract}
This paper explores the effect of dual-class shares on firm performance using a unique law change in Switzerland as a source of exogenous variation. Unlike most of the related literature we do not adopt a one-size-fits-all approach but allow the effect to vary depending on a firm's need for external finance. Based on nine years panel data of both firms affected and unaffected by the law change, we find that dual-class shares neither harm nor benefit firm performance on average. However, dual-class shares increase firm performance if the firm requires external finance and dual-class shares decrease firm performance if the firm does not require external finance.
\end{abstract}

Keywords: $\quad$ Corporate Governance, Dual-class Shares, Agency Theory, Stewardship Theory, Shareholder Value, Natural Experiment

Stephan Nüesch, University of Zurich, Department of Business Administration, Plattenstrasse 14, CH-8032 Zürich, Switzerland, phone: +41 4463429 14, email: stephan.nuesch@business.uzh.ch.

Acknowledgements: I am grateful to Brian Boyd, Will Mitchell, Pei Sung, participants at the 2011 Strategic Management Society Conference in Miami and seminar participants at the University of Konstanz for helpful comments. Data collection support from Stefan Hungerbühler and Nadine Trindler is gratefully acknowledged. The usual disclaimer applies. 


\section{INTRODUCTION}

If firms deviate from a one-share-one-vote principle by assigning disproportional voting rights to different classes of shares, dual-class shares emerge. While it seems natural that shareholders who provide equal amounts of equity should have equal opportunity to influence firm decisions, dual-class shares are frequent in reality. $35 \%$ of the 300 largest European firms have dual-class shares (Deminor Rating, 2005). In North America, the fraction of listed firms with dual-class shares is about 6 percent in the U.S. (Gompers, Ishi, \& Metrick, 2010) and 15 percent in Canada (Jog, Zhu, \& Dutta, 2010).

Dual-class shares create disproportionality between voting rights and cash flow rights. Prominent examples of firms with dual-class shares are Ford, Berkshire Hathaway, Google, and Facebook. Ford's dual-class equity structure allows the Ford family to control 40 percent of the firm's voting rights with only about 4 percent of the total equity in the firm. Warren Buffet, the majority shareholder of Berkshire Hathaway, holds shares with 200 times the voting right and (only) 30 times the cash flow right of ordinary shares (McClure, 2012). By holding shares with ten votes each share, the founders of Google (Sergey Brin and Larry Page) and the (former) CEO Eric Schmidt control two-thirds of the voting power, even though they own only one third of shares outstanding (Mills, 2006). A very similar equity structure puts Mark Zuckerberg, the founder and CEO of Facebook, in total command even after going public. Dual-class equity is typically created to help founders and other dominant owners to expand the firm without losing much control. The dominant owners, which we denote controlling shareholders in this study, typically concentrate their holdings in shares with superior voting rights, whereas minority shareholder primarily hold shares with inferior voting rights (Villalonga \& Amit, 2006; Villalonga \& Amit, 2009; Lauterbach \& Yafeh, 2011).

The effect of dual-class shares on firm performance is controversial. Opponents of dualclass equity argue that dual-class equity allows controlling shareholders to extract private 
benefits with few consequences (Grossman \& Hart, 1988; Harris \& Raviv, 1988; Masulis, Wang, \& Xie, 2009). Others, however, argue that dual-class equity is a value-enhancing governance structure because it helps controlling shareholders to pursue a long-term value creation strategy without fearing that short-term oriented raiders acquire the firm. As dualclass shares act as an anti-takeover device, they encourage incumbent managers to make firmspecific investments (DeAngelo \& DeAngelo, 1985; Lehn, Netter, \& Poulsen, 1992).

The empirical literature is yet to establish if and how dual-class shares affect firm value. The cumulative findings about the performance consequences of dual-class equity have been weak and/or inconsistent (for a review of the literature see Adams and Ferreira, 2007).

One difficulty in establishing a link between dual-class shares and firm performance is the endogeneity of a firm's equity structure. Endogeneity is a constant challenge to empirical corporate governance studies (e.g., Larcker, Ormazabal, \& Taylor, 2011) and a major issue when identifying the causal effect of dual-class shares on firm performance (Adams \& Ferreira, 2007; Bennedsen \& Nielsen, 2010). Firm performance and the equity structure are jointly determined. Omitted variables are therefore likely to affect both a firm's equity structure and performance, leading to spurious results. For example, incapable managers decrease firm performance by making bad decisions. At the same time, incapable managers may try to safeguard their position by issuing and holding shares with superior voting rights (Masulis et al., 2009).

Two recent studies (Gompers et al., 2010; Jog et al., 2010) address the endogeneity problem by using instrumental variables for dual-class shares. Both studies use a binary variable coded one when the founding family's name appears in the firm's name and a second variable coded one for firms in the media industry as instruments. However, these instruments are likely to affect firm performance beyond their influence on dual-class shares and, therefore, do not fulfill the exogeneity condition (Adams \& Ferreira, 2007; Bennedsen \& Nielsen, 2010). Family firms are often found to have different performances than other firms 
(e.g., Anderson \& Reeb, 2003) and media firms operate in a specific environment that may cause performance trends to be different than for firms in other industries. This study employs a law change in Switzerland as a natural experiment ${ }^{1}$ to mitigate the endogeneity problem. On October 4, 1991 the Swiss Parliament adopted a new corporation law (“Aktiengesetz") that removed specific advantages of having non-voting shares (NVS) in addition to voting shares: flexible issue of new shares and share buybacks and no minimum face value. Unlike with voting shares, no shareholder approval had been needed when increasing non-voting stock and firms had been able to buyback their NVS but not their voting shares. There had also been no minimum face value for NVS under the previous law. The new corporation law introduced a minimum face value for NVS, decreased the minimum face value for voting shares, and permitted buybacks for voting shares so that firms no longer have to resort to NVS for buybacks. As a result, the proportion of Swiss firms with NVS dropped from 47 percent in 1990 to 23 percent in 1994. We employ the law change as a source of exogenous variation in dual-class equity and identify the performance effects from panel data of both firms that are affected and firms that are unaffected by the law change, taking firm fixed effects and timevarying controls into account. ${ }^{2}$

A second difficulty in establishing a link between dual-class shares and firm performance is that one-size-does-not-fit-all. The effect of dual-class shares on a firm's performance is unlikely to be universally the same for all firms. It is not surprising that analyses seeking a universal effect yield weak and/or inconsistent results (e.g., Lins, 2003; Dimitrov \& Jain, 2006; Gompers et al., 2010, Jog et al., 2010). From the rich body of related empirical research

1 Recently, natural experiments have become an increasingly popular way to identify causal effects in corporate governance studies. Giannetti and Laeven (2008) tested the influence of ownership concentration on firm performance using a Swedish pension reform as a natural experiment. Bebchuk, Cohen, and Wang (2010) employed a Delaware Chancery Court ruling as a natural experiment to test the influence of staggered boards on share prices. Duchin, Matsusaka, and Ozbas (2010) used the board regulations of the SarbanesOxley Act 2002 to estimate the effect of board independence on performance.

2 Adams and Ferreira (2007) consider a combination of natural experiments and firm fixed effects as the gold standard for research on the effects of dual-class equity on firm performance. Natural experiments create sufficient within-firm variation for identification and firm fixed effects make the exogeneity assumption of the treatment assignment credible. 
only three studies (Masulis et al., 2009; Hoi \& Robin, 2010; Bennedsen \& Nielsen, 2010) have explored dual-class equity from a contingency perspective. This study extends the scarce contingency literature on the performance effects of dual-class equity by investigating the moderating influence of a firm's external financing needs. If a firm's internal cash flow exceeds profitable investment opportunities, the firm does not require external capital and monitoring by the capital markets is weak (Easterbrook, 1984; Jensen, 1984). This intensifies the potential agency conflicts between controlling and minority shareholders.

The main finding of this study is that dual-class shares neither increase nor decrease a firm's Tobin's q and return on asset (ROA) on average, but that a firm's external financing needs significantly moderate the relationship between dual-class shares and firm performance. As expected, we find that dual-class equity is associated with significantly better performance if a firm needs external finance, and with significantly worse performance if a firm does not need external finance.

The remainder of this article is structured as follows: In the next section, we give an overview of the theory and present testable hypotheses. We then explain the quasiexperimental setup and the institutional background of this study. Subsequently, we describe the data, the identification strategy, and present the empirical evidence. Finally, we discuss our results and conclude.

\section{THEORY AND HYOPOTHESES DEVELOPMENT}

\section{Negative View on Dual-Class Shares}

The negative view on dual-class shares is rooted in agency theory. Agency theory describes the costs associated with the separation of ownership and control (Jensen \& Meckling, 1976; Vishny \& Shleifer, 1997). Controlling shareholders exercise direct or indirect control over the firm. Minority shareholders, while participating in the ownership of the firm, have little to 
say. Agency costs in this context arise if controlling shareholders pursue their own interests that conflict with the interests of minority shareholders.

If controlling shareholders have disproportionally more voting rights than cash flow rights, they bear a smaller proportion of the financial consequences of their decisions while having a greater ability to extract private benefits (Masulis et al., 2009). In addition, dualclass shares protect entrenched controllers against the market for corporate control. Overall, dual-class shares reduce the costs of consuming perquisites and enjoying private benefits and therefore intensifies the agency conflict between controlling shareholders and minority shareholders (Burkart \& Lee, 2008).

Assuming self-interested individuals and a setting where the controlling shareholders obtain private benefits of control, the theoretical analyses of Grossman and Hart (1988) and Harris and Raviv (1988) show that a one-share-one-vote equity structure is optimal as it minimizes the likelihood that a value-enhancing takeover would not be realized. In firms with dual-class equity, the controlling shareholders with the better management team do not always win in takeover bidding contests.

Several empirical studies have confirmed the negative view on dual-class equity. The event study of Jarrell and Poulsen (1988) finds significantly negative announcement effects of dual-class recapitalizations on stock prices. A negative value impact of dual-class equity is also documented by Claessens, Djankov, Fan, and Lang (2002) for firms in East Asia, by Lins (2003) for firms in 18 emerging markets and by Villalonga and Amit (2009) for firms in the U.S.. Examining the channels through which dual-class equity affects share prices, Masulis et al. (2009) show that firms with dual-class shares have higher CEO salaries and that shareholders value the firm's cash, acquisitions and capital spending less than in firms with single-class equity. Thus, dual-class shares reduce firm value to (minority) shareholders as the CEO receives higher salaries and engages in more inefficient empire-building activities. Whereas endogeneity challenges the negative associations in the above-mentioned studies, 
this study tries to replicate their findings using the exogenous variation of a natural experiment. Thus, we predict that:

Hypothesis 1: Dual-class shares decrease firm performance, ceteris paribus.

\section{Positive View on Dual-Class Shares}

The positive view on dual-class shares roots in the stewardship theory of management and in the assumption of myopic financial markets. Whereas the agency perspective assumes that controlling shareholders behave opportunistically at the costs of minority shareholders, the stewardship perspective (Davis, Schoorman, \& Donaldson, 1997) suggests that individual behavior is not simply guided by self-interest but by service to others. The higher the identification with the firm, the higher the intrinsic motivation to work toward the firm's goals tends to be (Davis et al., 1997).

According to the stewardship perspective, barriers to the market for corporate control in the form of dual-class shares are not necessarily bad. To the contrary, removing all barriers to the market for control could force otherwise diligent managers and controlling shareholders to concentrate only on the current share price and neglect long-term value creation. Dual-class shares enable controlling shareholders to repel attempts of unfriendly takeover by a relatively small investment in the equity of the firm. Specifically, firms may benefit from such an antitakeover device in two ways: First, dual-class shares encourage incumbent managers to invest in firm-specific human capital. Managers tend to be reluctant to make firm-specific investments if potential takeovers threaten their (future) employment (DeAngelo \& DeAngelo, 1985). Second, firms may benefit from dual-class shares if financial markets undervalue long-term investments and share prices do not fully reflect future cash flows prospects. In such a setting, knowledgeable raiders could take control of the firm at an unreasonably low price. Dual-class shares, however, allow the likewise knowledgeable controlling shareholders to prevail against raiders by a smaller investment in the equity of the 
firm. The theoretical analyses of Chemmanur and Jiao (2012) show that dual-class equity is a value-enhancing equity structure if the firm's activities are characterized by high near-term uncertainty defined as "intrinsically more valuable, but showing less signs of success in the near-term" (p. 316). Dual-class shares increase the probability that the incumbent has enough votes to prevail against any myopic rival and to continue the profitable but uncertain projects.

Partch (1987) finds the announcement of plans to create limited voting common stock to have positive valuation effects. Lehn et al. (1990) and Dimitrov and Jain (2006) show that shareholders earn significantly higher returns following dual-class recapitalizations. Firms that change from single-class into a dual-class equity structure grow faster than control firms and do not suffer from increased managerial entrenchment. This study tries to replicate the positive associations between dual-class shares and firm performance found in previous studies by making use of a natural experiment. Thus, we predict that:

Hypothesis 2: Dual-class shares increase firm performance, ceteris paribus.

\section{Need for External Finance as a Moderator}

As described in the previous two sections, the agency perspective highlights the detriments and the stewardship perspective the benefits of dual-class shares. Although each distinct research stream is individually compelling, elements of both perspectives are likely to be present in practice. The critical question is under what contextual factors do the benefits of dual-class equity described by the stewardship perspective outweigh the potential abuses described by the agency perspective? The inherent trade-off is unlikely to be the same for all firms. Rather, contextual factors are expected to intervene between dual-class equity and firm performance. Even though such a contingency view is essential for the equity structure to be a source of competitive advantage, only three empirical studies have taken a contingency view on dual-class equity so far (Masulis et al., 2009; Hoi and Robin, 2010, Bennedsen and Nielsen, 2010). 
An important but underexposed contextual factor is the need for external finance. Referring to the seminal studies of Easterbrook (1984) and Jensen (1986) we argue that a firm's external financing needs attenuate the agency conflict between controlling and minority shareholders.

If the internally generated cash flow exceeds profitable investment opportunities, the firm does not need to obtain external finance, which weakens monitoring by the capital market. If a firm requires external finance and therefore issues new securities, however, the firm's affairs will be rigorously reviewed. Because contributors of new capital can, unlike existing investors, refuse to invest money in the firm, controlling shareholders who need to raise money are more likely to act in the minority shareholders' interests than controlling shareholders who are immune from this kind of scrutiny. A firm's existing investors can influence actions only by voting (which suffers from a collective action problem) and by selling their shares (mostly at lower prices). All in all, external financing needs mitigate the agency costs between controlling and minority shareholders and create a context in which the benefits of dual-class shares are likely to outweigh the costs of dual-class shares. We therefore predict that:

Hypothesis 3: A firm's need for external finance positively moderates the relation between dual-class shares and firm performance.

\section{BACKGROUND OF THE NATURAL EXPERIMENT}

\section{Different Share Classes}

Swiss firms can issue three major classes of shares: registered shares (RS), bearer shares (BS), and non-voting shares (NVS). While all three classes of shares receive dividends that are proportional to their face values, only RS and BS possess voting rights, namely one vote each share. NVS (in German "Partizipationsscheine") are not entitled to any voting rights. The 
main difference between RS and BS is that the holders of BS remain anonymous to the firm whereas the buyers of RS have to be registered by the firm to claim the rights vested in the stock.

\section{Law Change}

On October 4, 1991, the Swiss Parliament passed a new corporation law (“Aktiengesetz") that took effect on July 1, 1992. The new law caused an exogenous shock to the fraction of firms with NVS as it abolished three specific advantages of having NVS that can be described with the terms liquidity, protectionism, and financial flexibility.

First, the new law required that all classes of shares have a minimum face value of 10 CHF. It introduced a minimum face value for NVS and decreased the minimum face values for voting shares from $100 \mathrm{CHF}$ to $10 \mathrm{CHF}$. Thus, firms could no longer increase share liquidity by issuing NVS with very low face values. Unlike with BS and RS, there had not been a minimum face value for NVS under the previous law.

Second, the new corporation law significantly curtailed discrimination against unwanted investors and abolished nationality as a valid criterion for denying ownership to buyers of RS of listed firms. Protectionism used to be an important reason for creating dual-class equity in Switzerland. The previous corporation law had allowed Swiss firms to discriminate across investor type by rejecting prospective holders of RS without providing specific reasons. A frequently used criterion had been that shareholders had to be Swiss nationals. However, due to the limited financial power of Swiss investors, large firms had not been able to obtain sufficient domestic capital and therefore had frequently issued an unrestricted class of shares as well. Since NVS are not entitled to any voting rights, NVS had been particularly suitable for protective firms requiring external foreign capital. Under the new corporation law, firms can no longer seek non-voting foreign capital only. 
Third, the new corporation law also removed financial flexibility as a reason for having NVS. Because NVS had not even been mentioned in the previous corporation law, firms had been able to issue and withdraw NVS in a very flexible manner. Unlike with voting shares, no shareholder approval had been needed when increasing non-voting stock and firms had been able to buy back their NVS whenever they wanted. Firms had not been allowed, however, to buy back their own voting shares. The new corporation law created more flexible ways to increase capital of voting stock and permitted buybacks of voting shares. In addition, the new law regulated NVS and designed them as shares with the same rights and duties as the voting shares except that they do not have voting rights.

The new corporation law also limited the fraction of non-voting stock to a maximum of double the voting stock. But this regulation did not change much. Our data reveal only one firm for which the non-voting stock was more than double the voting stock. In addition, exception was granted for firms that had non-voting stock more than double the voting stock already in 1985 (grandfather clause).

By removing the three previous advantages of having NVS (liquidity, protectionism, financial flexibility), the law change caused a substantial number of firms to abandon NVS. The decrease in the fraction of firms with NVS is considered as exogenous in a firm performance model because the reasons for abandoning NVS are not related to the efficiency arguments of dual-class shares outlined in the theoretical section. Firms had to ensure their bylaws complied with the new corporation law within five years, by June 30, 1997 at the latest. Since that date, the law has been strictly enforced and non-compliant firms could have been dissolved per curiam. Whereas the average fraction of listed Swiss firms with NVS was 47 percent in 1990, it decreased to 23 percent by 1994. 


\section{SAMPLE AND VARIABLES}

This study uses yearly observations from publicly listed Swiss firms from 1989 to 1997 . A firm's equity structure, its largest shareholder and the firm's age have been hand-collected from annual versions of the Swiss Stock Guide ("Aktienführer Schweiz”), which describe all listed firms in Switzerland, 345 unique firms and 2137 firm-year observations in total. Data on firm performance, external financing needs, firm size and other firm-specific variables are taken from the Thomson Reuters Datastream database. In principle, Datastream provides historical data from the late 80 s onward. However, data from the early years are less complete and historical data of firms that went bankrupt or were acquired are often missing.

We merged the two data sets based on firm name and year. As name formats may differ between the two data sources, firm names had to be cleaned. In addition, we had to manually check whether a firm name might have changed. After that, we were able to merge correspondent Datastream data for 196 firms and 1242 firm-year observations.

Insert Table 1 about here

As our sample does not cover all of the listed firms in Switzerland, non-random sample selection could bias our results. In Table 1 we assess the representativeness of our sample. While firms with NVS are slightly overrepresented in our sample, the difference in means is not statistically significant. The mean age of the firms in our sample is also statistically indistinguishable from that of all firms listed on the Swiss stock market in that period of time. Overall, our sample seems to be representative of the Swiss stock market. It includes both big firms with a global coverage like ABB, Nestle, Novartis, Roche, and UBS and medium sized (family) firms. 


\section{Dependent Variables}

We measure firm performance in two ways: return on assets (ROA) and Tobin's q. ROA is a standard accounting measure of financial performance commonly found in corporate governance and strategy research (e.g., Jog et al., 2010) and is calculated by dividing annual earnings before interest by average total firm assets. We use Tobin's q in addition to ROA, because Tobin's q better reflects the future profit and growth potential of a firm. We calculated Tobin's q by dividing the sum of the market value of a firm's equity and the book value of its debt by the book value of total assets.

We follow the related literature (e.g., Gompers et al., 2010; Jog et al., 2010) and adjust firm performance measures by industry specific time trends. Specifically, we deduct from the firm's ROA and Tobin's q the value-weighted industry average of Tobin's q and ROA, respectively. As industry classifications, we use the first digit of the Industry Classification Benchmark (www.icbenchmark.com).

\section{Instrument, Intervening and Moderating Variables}

We measure the existence of dual-class shares using a dummy variable $N V S_{i t}$ that equals 1 if a firm has NVS in a given year and 0 otherwise. As argued in the introduction, a simple regression relating firm performance to its equity structure is likely to be confounded by omitted variables that may affect both the firm's equity structure and performance. The standard textbook solution to mitigating the endogeneity problem is to use instrumental variables estimation (Wooldridge, 2002). Adequate instruments are hard to find, however. In this study, we make use of the law change that decreased the convenience of NVS to construct an instrument. Specifically, we employ the dichotomous variable $L a w_{i t}$ as instrument for dual-class equity. $L a w_{i t}$ equals 1 for affected firms (i.e., firms with NVS in 
1991) in the post-policy period (between 1992 and 1997). ${ }^{3}$ As the results of the first-stage regressions will show, $L a w_{i t}$ is an important negative predictor of dual-class shares.

To test whether the influence of dual-class shares on firm performance depends on a firm's external financing needs, we include an interaction term of the predicted values of dual-class equity from the first-stage regression and a proxy of a firm's external financing needs. A firm requires external finance if the investment opportunities exceed internal cash flow. To measure a firm's internal cash flow and its optimal investment level, we follow the approach established by Demirgüç-Kunt and Maksimovic (1998) and applied by Durnev and Kim (2005) and Chen, Chung, Hsu, and $\mathrm{Wu}$ (2010). They define external financing needs as the difference between the firm's actual growth rate and the sustainable growth rate. The actual growth rate of a firm is defined as the annual growth rate in total assets. The sustainable growth rate is defined as the growth rate attainable if the firm does not pay dividends and receives just enough debt financing to maintain a constant debt-to-assets ratio. Under these assumptions, the sustainable growth rate equals ROE/(1-ROE), where ROE is net income over book equity (see Demirgüç-Kunt \& Maksimovic, 1998, and Durnev \& Kim, 2005 , for a detailed derivation of this formula). If the difference between actual growth rate and the sustainable growth rate is positive, the firm needs external finance. If the difference is negative, the firm generates more internal funds than needed to finance firm growth. To avoid endogeneity issues we use the difference between the actual and sustainable growth rates from the previous year to measure a firm's external financing needs.

We prefer this proxy of a firm's reliance on external finance to the free cash flow proxy suggested by Brush, Bomiley, and Hendrickx (2000). Based on the seminal work of Lang, Stulz, and Walking (1991), Brush et al. (2000) argue that free cash flow equals cash flow (operating income before depreciation, minus interest expense, taxes, and dividends) for firms

\footnotetext{
3 The instrumental variable $\operatorname{Law}_{i t}$ is set to 0 for firms that did not exist or were not listed in 1991.
} 
with Tobin's q below 1 , but is zero for firms with Tobin's q above 1 , because firms with Tobin's q above 1 have profitable investment opportunities in theory. While such a measure of free cash flow may be appropriate in models of sales growth (see Brush et al., 2000), it causes significant endogeneity issues in firm performance models (see also Lang et al., 1991, for limitations of the free cash flow proxy).

\section{Control Variables}

Adequate instruments have to significantly influence the endogenous variable, but must not be correlated with the structural error term. Whereas the first condition can be tested by the Fstatistics of the identifying instrument $L a w_{i t}$ in a regression explaining the endogenous variable, there is no empirical test for the second condition because of the unobservability of the structural error term. ${ }^{4}$ The instrument must be uncorrelated with the dependent variable in the second-stage equation, except through variables that are included in the equation. Thus, we have to diligently check the control variables.

We remove confounding influences by controlling for factors that may correlate with both the instrument $L a w_{i t}$ and firm performance. Previous literature has shown that firm performance is negatively related to a firm's external financing needs (Chen et al., 2010), firm age (Loderer \& Wälchli, 2010), firm size (e.g., Claessens et al., 2002; Hoi \& Robin, 2010), and positively related to research intensity (Hoi \& Robin, 2010), firm leverage (Jog et al., 2010), and family firm status (Anderson \& Reeb, 2003). As such observable characteristics may differ between firms affected by the law change and firms unaffected, we include a firm's external financing needs, firm age (number of years since incorporation, transformed by logarithm), firm size (firm's assets, transformed by logarithm), the ratio of research and

4 If the number of instruments exceeded the number of endogenous variables, tests of over-identifying restrictions (Hansen, 1982) could be applied to examine the second condition. This test requires, however, that at least one of the instruments is valid (Larcker and Rusticus, 2010). As we have a perfectly identified model, tests for over-identifying restrictions are anyway not possible in our case. 
development (R\&D) expenditures to net sales, firm leverage (debt to equity ratio) and a dummy variable indicating family firms (dummy variable equaling 1 if largest shareholder holds more than $50 \%$ of the votes) as controls. To take common time trends of dual-class equity into account we also include year fixed effects.

To avoid problems with outlying observations, we winsorize all variables at the 5 st and the 95th percentile. Following Miller et al. (2007) we coded missing values for R\&D to sales as 0 . All variables (except binary variables) are standardized to increase the interpretability of the estimates and to reduce multicollinearity of the interaction variables.

\section{RESULTS}

\section{Descriptive Statistics}

Table 2 provides descriptive statistics of the (unstandardized) variables. The firms in our sample have an average ROA of 4.48 percent and a Tobin's q of 1.19 . The average fraction of firm-year observations with NVS is 34 percent. On average, firms generate just sufficient internal funds to finance firm growth (mean of the external financing needs variable is 0 ). The standard deviation of 0.20 indicates that some firms generate more and other firms less internal funds than needed. Mean log firm age is 3.69 (40 years) and mean log assets 13.70 (around 890 million CHF). R\&D expenditures correspond to 0.78 percent of sales and the leverage ratio is 4.08 , on average. The fraction of family firm observations is $69 \%$.

Insert Table 2 about here

Table 3 compares firms with NVS (affected firms) to firms without NVS (unaffected firms) in 1991, one year before the law change. Firms with and without NVS did not significantly differ in firm performance. Firms with and without NVS had very similar external financing needs. Affected firms were, however, older and larger than unaffected 
firms. Whereas the $\mathrm{R} \& \mathrm{D}$ expenditures to sales ratio and the leverage ratio were not significantly different in affected and unaffected firms, family firms were slightly underrepresented in the group of firms with NVS.

Insert Table 3 about here

The (partly) significant differences between affected and unaffected firms confirm the importance of controlling for the observable factors that previous studies found to influence performance. By controlling for a firm's external financing needs, firm age, assets, R\&D expenditures to sales ratio, leverage ratio and family firm status we remove confounding influences based on these observable firm characteristics.

\section{Model Specification and Estimation}

A potential problem is that our controls only partly cover all relevant firm characteristics. Larger firms may have different firm cultures, business strategies and managerial quality than smaller firms, for example. As larger firms are also more likely to have NVS and therefore to be affected by the law change, performance comparisons of affected and unaffected firms may be biased even when controlling for observable factors such as a firm's total assets. To control for the possibility of unobserved time-invariant determinants of firm performance such as firm cultures, we make use of the panel dimension of our data. Formally, we decompose the structural error term $\left(\epsilon_{i t}\right)$ into a firm-specific disturbance $\left(u_{i}\right)$ and an independent and identically distributed error term $\left(\varepsilon_{i t}\right)$ so that $\epsilon_{i t}=u_{i}+\varepsilon_{i t}$.

F tests following fixed-effects regressions indicate that there is a significant firm-specific disturbance (F-statistics are between 4.5 and 12.6, p<0.001), implying that the method of pooled Ordinary Least Squares (OLS) is inappropriate. The firm-specific disturbance can be either fixed over time for each firm (fixed-effects model), or vary randomly over time for 
each firm (random-effects model). To decide whether the firm-level effects are random or fixed, we performed the Hausman specification test (Hausman, 1978) that compares the fixedeffects estimates with the random-effects estimates. Whereas the fixed-effects model allows the firm-level effects to be correlated with the explanatory variables, the random-effects model assumes strict orthogonality. The Hausman specification test rejects the orthogonality assumption at high levels of statistical significance, which suggests that a random-effects model inadequately describes firm-level effects.

By using a firm fixed-effects model, we control for the possibility of unobservable timeconstant determinants of performance. Essentially, we compare the performance changes of firms that abandoned NVS due to the law change with the performance changes of firms that did not abandon NVS; regression adjusted for observable time-varying determinants of firm performance and common time trends. Inference is based on robust standard errors clustered at the firm level to take serial error correlations across firm observations into account (Peterson, 2009). The estimates are unbiased as long as the law change is uncorrelated to unobserved time trends of confounding variables. Confounding factors that could change over time are managerial quality or the firm's main business strategy, for example. However, we see no special patterns in CEO dismissals around 1992 and it is very unlikely that the altered regulations of NVS caused firms to change their main business strategy.

\section{Regression Results}

In a first step we predict a firm's NVS with the identifying instrument and the control variables (including firm fixed effects). In a second step we relate the predicted values of the first-stage regressions to firm performance.

Insert Table 4 about here 
Table 4 reports the results. $p$-values based on standard errors adjusted for heteroskedasticity (White, 1980) and firm clustering (Peterson, 2009) are reported in parentheses. Model 1 shows the estimates of the first-stage regression. The instrument $\operatorname{Law}_{i t}$ (equaling 1 for firms with NVS in 1991 for observations after 1991, 0 otherwise) is a strong negative predictor. The fraction of firms with NVS decreased by 43 percent for affected firms in the after-policy period, controlling for time-varying controls and timeconstant firm heterogeneity. The partial $\mathrm{R}^{2}$ value of 0.14 of the identifying instrument documents the relevance of our instrument when explaining $N V S_{i t}$ (Bound, Jaeger, \& Baker, 1995). The F-statistic $(70.13, \mathrm{p}<0.001)$ is far above the critical value of 8.96 (Larker \& Rusticus, 2010).

The predicted values from the first-stage regressions are used as explanatory variables in the second-stage regressions. Models 2 and 3 in Table 4 report the results when testing hypotheses 1 and 2 of universal effects of dual-class equity on firm performance. The effects of the predicted values of $N V S_{i t}$, are negative when using the industry-adjusted ROA as performance measure and positive when using the industry-adjusted Tobin's q as performance measure. However, the effects are not statistically different from zero. Thus, neither Hypothesis 1, predicting a negative performance effect of dual-class shares, nor Hypothesis 2, predicting a positive performance effect of dual-class shares, is supported. The effects of the control variables are mostly insignificant. Exceptions are the effects of external financing needs and the leverage ratio (significantly negative effects on ROA) and firm assets (significantly negative effect on Tobin's q).

Models 4 and 5 in Table 4 show the results of a specification that additionally includes an interaction term of the predicted values of $N V S_{i t}$ and a firm's external financing needs. The coefficients of the interaction term are significantly positive in both models. As the interaction variables are mean-centered and as the mean of the external financing needs variable is 0 , a positive interaction effect implies that dual-class shares increase firm performance if the firm 
needs external finance (external financing variable above 0), and that dual-class shares decrease firm performance if the firm does not need external finance (external financing needs variable below 0). ${ }^{5}$ Thus, Hypothesis 3 predicting that a firm's external financing needs positively moderate the relation between dual-class shares and performance is confirmed. The effects of the control variables and the direct effect of dual-class equity do not change in any significant way when including the interaction term.

\section{CONCLUSIONS}

This study uses a law change to explore the causal effect of dual-class shares on firm performance. Performance effects are identified based on panel data of both firms affected and unaffected by the law change, taking unobserved firm heterogeneity and time-varying controls into account. We find that dual-class shares increase firm performance if a firm needs external finance and decrease firm performance if a firm does not need external finance, leading to an insignificant universal effect.

How can these findings be explained? Given that dual-class shares, as most corporate governance practices, have both advantages and disadvantages, insignificant universal performance effects should be no surprise (Aguilera, Filatotchev, Gospel, \& Jackson, 2008). The positive and negative effects could simply neutralize each other. But why do external financing needs create a context in which the advantages of dual-class equity outweigh the disadvantages of dual-class equity?

Excess internal funds insulate controlling shareholders from the monitoring of the capital market. The weak monitoring of the capital market intensifies the agency conflict between controlling shareholders and minority shareholders and thereby also intensifies the

5 To test for potential non-linearity of the interaction effect, we conducted subsample analyses. The performance effects of the predicted values of dual-class equity are insignificant when estimated separately for a subsample of firms with external financing needs and a subsample of firms without external financing needs. However, as the cases-to-variables ratio is far below 10, the statistical power of the subgroup analyses is low. 
disadvantages of dual-class equity. By holding shares with superior voting rights and by having sufficient internal cash flow to fund all firm projects, controlling shareholders are unlikely to be replaced by rivals or disciplined by the capital market. The coexistence of dualclass equity and excess internal funds therefore facilitates private rent extractions and inefficient empire-building activities by controlling shareholders at the cost of minority shareholders.

If profitable investment opportunities exceed internal cash flow, the situation is quite different. As the firm needs external finance, controlling shareholders are under much stronger market discipline and have less leeway to pursue their own objectives. This reduces conflicts of interests between controlling and minority shareholders regardless of whether dual-class equity exists or not. In fact, our results indicate that fast growing firms may benefit from dual-class equity as an anti-takeover device that encourages stable ownership and firmspecific investments.

This study contributes to the existing literature in three key aspects: We are the first to address the endogeneity of dual-class equity by making use of a natural experiment. The unique law change in Switzerland created an exogenous shock to equilibrium governance practices. Thus, the "within equilibrium" criticism (Larcker et al., 2011) does not apply to this study. Second, while previous research has mostly investigated universal performance effects of dual-class shares (e.g., Gompers et al., 2010; Jog et al., 2010), this study emphasizes a contingency view on dual-class equity. Such a contingency view is indispensable for an equity structure to create a competitive advantage. Third, the finding that a firm's external financing needs positively moderate the relationship between dual-class shares and firm performance sheds a fresh light on a related study by Chen et al. (2010). They argue that firms with external financing needs tend to have better governance practices because improvements in corporate governance reduce the costs of raising external capital. They find significantly positive interaction effects of external financing needs and a general governance quality index 
on firm performance. ${ }^{6}$ Even though dual-class equity is commonly considered as weak corporate governance (Gompers et al., 2010), we show that this is not true for fast growing firms with external financing needs. The performance of such firms benefits from dual-class equity as it shields them from potential hostile takeovers and enables the controlling shareholders (usually the founders) to pursue a long-term value creation strategy.

\section{Limitations and Future Research}

Despite these contributions, this study has some caveats or limitations that need future research to enhance its key arguments. First, as the identification strategy is based on a unique law change in Switzerland, future studies should replicate this study in other countries to test the generalizability of our results. Second, our empirical strategy delivers estimates of the effectiveness of abandoning NVS in response to a law change that removed comparative advantages of NVS. Using only the within-firm variation, we cannot determine whether the firms that did not change their equity structure were guided by rent extraction or value maximization considerations. We simply know that, on average, the performance trend of "changers" was very similar to the performance trend of "stayers". Third, some of our empirical analyses are constrained by the availability of the data. Future studies with access to more detailed data could test additional moderators related, for example, to the composition of the management team. As founding families tend to identify very strongly with "their" firm, the stewardship theory conjectures that the presence of family members in the management team should enhance the benefits of dual-class equity. Previous evidence on this topic (e.g., Villalonga \& Amit, 2006; Hoi \& Robin, 2010) is inconclusive.

6 As Chen et al. (2010) use a corporate governance index that is inversely coded with a large value indicating poor corporate governance quality, the interaction effect is in fact negative. 


\section{Managerial Implications}

The results of this study have clear managerial implications. Dual-class shares are not suitable for firms with low long-term growth, for which internally generated funds exceed opportunities to invest them profitably. Such firms should create a one-share-one-vote structure to reduce the risk of private rent extractions by controlling shareholders. However, fast growing firms that need external finance to fund their projects should create dual-class equity to promote stable ownership and firm specific investments. The capital market mitigates the agency conflicts between controlling and minority shareholders for such firms and both parties benefit from dual-class equity as an anti-takeover device.

From a policy perspective, the results of this study indicate that policy makers do well to not prohibit dual-class shares in general. As the performance consequences of dual-class shares depend on firm characteristics such as the need for external finance, there is no onesize-fits-all approach.

\section{REFERENCES}

Adams, R. \& Ferreira, D. 2007. One share, one vote: The empirical evidence. ECGI Working Paper Series in Finance, European Corporate Governance Institute.

Aguilera, R. V., Filatotchev, I., Gospel, H., \& Jackson, G. 2008. An organizational approach to comparative corporate governance: Costs: contingencies, and complementarities. Organization Science, 19: 475-492.

Anderson, R. C. \& Reeb, D. M. 2003. Founding-family ownership and firm performance: Evidence from the S\&P 500. The Journal of Finance, 58: 1301-1327.

Angrist, J. D. \& Krueger, A. B. 2001. Instrumental variables and the search for identification: From supply and demand to natural experiments. Journal of Economic Perspectives, 15: 69-85. 
Bebchuk, L. A., Cohen, A., \& Wang, C. C. Y. 2010. Staggered Boards and the Wealth of Shareholders: Evidence from a Natural Experiment. Working paper, Harvard Law and Economics Discussion Paper No. 697.

Bennedsen, M. \& Nielsen, K. M. 2010. Incentive and entrenchment effects in European ownership. Journal of Banking and Finance, 34: 2212-2229.

Bound, J., Jaeger, D. A., Baker, R. M. 1995. Problems with instrumental variables estimation. When the correlation between the instruments and the endogenous explanatory variables is weak. Journal of American Statistical Association, 90: 443-450.

Brush, T. H, Bromiley, P., \& Hendrickx, M. 2000. The free cash flow hypothesis for sales growth and firm performance. Strategic Management Journal, 21: 455-472.

Burkart, M. \& Lee, S. 2008. One share - one vote: the theory. Review of Finance, 12: 1-49.

Claessens, S., Djankov, S., Fan, J. P. H., \& Lang, L. H. P. 2002. Disentangling the incentive and entrenchment effects of large shareholdings. The Journal of Finance, 57: 2741-2771.

Chen, W.-P., Chung, H., Hsu, T.-L., Wu, S. 2010. External financing needs, corporate governance, and firm value. Corporate Governance: An International Review, 18: 234249.

Chemmanur, T. J. \& Jiao, Y. 2012. Dual class IPOs: A theoretical analysis. Journal of Banking and Finance, 36: 305-319.

Davis, J. H., Schoorman, F. D., \& Donaldson, L. 1997. Toward a stewardship theory of management. The Academy of Management Review, 22: 20-47.

DeAngelo, H. \& DeAngelo, L. 1985. Managerial ownership of voting rights: a study of public corporations with dual classes of common stock. Journal of Financial Economics, 14: 3369.

Deminor Rating. 2005. Application of the one share - one vote principle in Europe. Report of the Association of British Insurers. 
Demirgüç-Kunt, A. \& Maksimovic, V. 1998. Law, finance, and firm growth. Journal of Finance, 53: 2107-2137.

Dimitrov, V. \& Jain, P. C. 2006. Recapitalization of one class of common stock into dualclass: Growth and long-run stock returns. Journal of Corporate Finance, 12: 342-366.

Duchin, R., Matsusaka, J. G., \& Ozbas, O. 2010. When are outside directors effective? Journal of Financial Economics, 96: 195-214.

Durnev, A. \& Kim, E. H. 2005. To steal or not to steal: Firm attributes, legal environment, and Valuation. Journal of Finance, 60: 1461-1493.

Easterbrook, F. H. 1984. Two agency-cost explanations of dividends. The American Economic Review, 74: 650-659.

Giannetti, M. \& Laeven, L. 2008. Pension reform, ownership structure, and corporate governance: evidence from a natural experiment. Review of Financial Studies, 22: 40914127.

Gompers, P., Ishi, J., \& Metrick, A. 2010. Extreme Governance: an analysis of dual-class firms in the United States. Review of Financial Studies, 23: 1051-1088.

Grossman, S. J. \& Hart, O. D. 1988. One share-one vote and the market for corporate control. Journal of Financial Economics, 20: 175-202.

Hansen, L. P. 1982. Large sample properties in generalized methods of moments estimator. Econometrica, 50: 1029-1054.

Harris, M. \& Raviv, A. 1988. Corporate governance: voting rights and majority rules. Journal of Financial Economics, 20: 203-235.

Hausman, J. A. 1978. Specification tests in econometrics. Econometrica, 46: 1251-1271.

Hoi, C-K. \& Robin, A. 2010. Agency conflicts, controlling owner proximity, and firm value: An analysis of dual-class firms in the United States. Corporate Governance: An International Review, 18: 124-135. 
Jarrell, G. \& Poulsen, A. 1988. Dual-class recapitalizations as anti-takeover mechanisms. Journal of Financial Economics, 20: 129-152.

Jensen, M. C. \& Meckling, W. H. 1976. Theory of the firm. Managerial behavior, agency costs and ownership structure. Journal of Financial Economics, 3: 305-360.

Jensen, M. C. 1986. Agency costs of free cash flow, corporate finance, and takeovers. American Economic Review, 76: 323-329.

Jog, V., Zhu, P., \& Dutta, S. 2010. Impact of restricted voting share structure on firm value and performance. Corporate Governance: An International Review, 18: 415-437.

Lang, L. H. P., Stulz, R. M., \& Walking, R. A. 1991. A test of the free cash flow hypothesis : The case of bidder returns. Journal of Financial Economics, 29 : 315-335.

Larcker, D. F. \& Rusticus, T. O. 2010. On the use of instrumental variables in accounting research. Journal of Accounting and Economics, 49: 186-205.

Larcker, D. F. \& Ormazabal, G., \& Taylor, D. J. 2011. The market reaction to corporate governance regulation. Journal of Financial Economics, 101: 431-448.

Lauterbach, B. \& Yafeh, Y. 2011. Long term changes in voting power and control structure following the unification of dual class shares. Journal of Corporate Finance, 17: 215-228.

Lehn, K., Netter, J., \& Poulsen, A. 1990. Consolidating corporate control: dual-class recapitalizations versus leveraged buyouts. Journal of Financial Economics, 27: 557-580.

Lins, K. V. 2003. Equity ownership and firm value in emerging markets. Journal of Financial and Quantitative Analysis, 38: 159-184.

Loderer, C. \& Wälchli, U. 2010. Firm age and performance. Working paper, University of Berne.

Masulis, R. W., Wang, C., \& Xie, F. 2009. Agency problems at dual-class companies. The Journal of Finance, 64: 1697-1727. 
McClure, B. 2012. The two sides of dual-class shares.

http://www.investopedia.com/articles/fundamental/04/092204.asp\#axzz1m4jNRzGU, accessed February 11, 2012.

Miller, D., Breton-Miller, I. L., Lester, R. H., \& Cannella, A. A. 2007. Are family firms really superior performers? Journal of Corporate Finance, 13: 829-858.

Mills, E. 2006. Google to defend dual-class stock structure.

http://www.zdnet.com/news/google-to-defend-dual-class-stock-structure/147623, accessed February 13, 2012.

Murphy, K. R., Myors, B., \& Wollach, A. 2009. Statistical Power Analysis. A Simple and General Model for Traditional and Modern Hypothesis Tests. New York: Routledge.

Partch, M. 1987. The creation of a class of limited voting common stock and shareholder wealth. Journal of Financial Economics, 18: 313-339.

Peterson, M. A. 2009. Estimating standard errors in finance panel data sets: Comparing approaches. Review of Financial Studies, 22: 435-480.

Villalonga, B. \& Amit, R. 2006. How do family ownership, control and management affect firm value? Journal of Financial Economics, 80: 385-417.

Villalonga, B. \& Amit, R. 2009. How are U.S. family firms controlled? Review of Financial Studies, 22: 3047-3091.

Vishny, A. \& Shleifer, R. 1997. A survey of corporate governance. The Journal of Finance, 52: 737-783.

White, H. 1980. A heteroskedasticity-consistent covariance matrix estimator and a direct test for heteroskedasticity. Econometrica, 48: 817-838.

Wooldridge, J. M. 2002. Econometric Analysis of Cross Section and Panel Data. Cambridge/London: The MIT Press. 
TABLE 1

Representativeness of the Sample

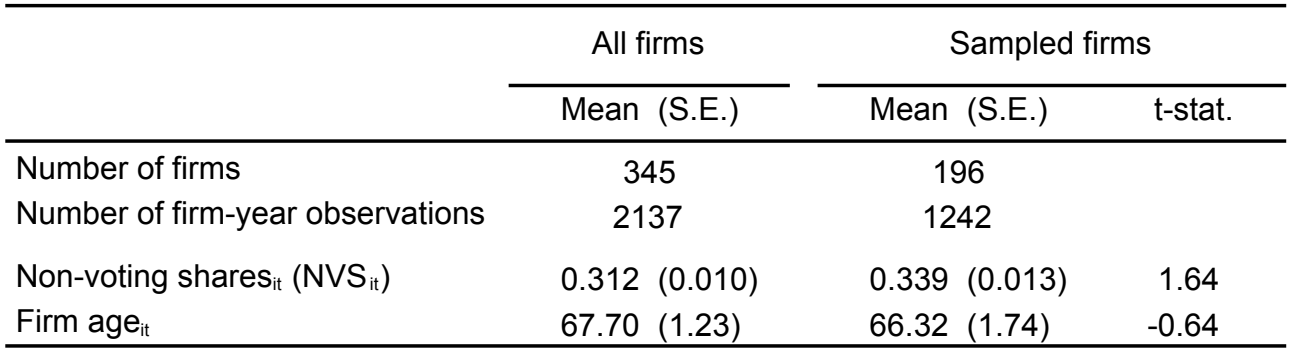

Source: Annual versions of the Swiss Stock Guides 1989 to 1997, own calculations. The table reports descriptive statistics of all listed Swiss firms between 1989 and 1997 and of the sampled firms.

Significance levels are denoted by *** 0.1 percent, ${ }^{* *} 1$ percent, * 5 percent, $\dagger 10$ percent (two-tailed tests). 
TABLE 2

Descriptive Statistics

\begin{tabular}{lrrrr}
\hline Variables & Mean & s.d. & Min & Max \\
\hline ROA $_{\text {it }}\left(10^{2}\right)$ & 4.48 & 3.50 & -1.14 & 12.41 \\
Tobin's q $_{\text {it }}$ & 1.19 & 0.37 & 0.79 & 2.24 \\
Non-voting shares $_{\text {it }}\left(\mathrm{NVS}_{\text {it }}\right)$ & 0.34 & & 0.00 & 1.00 \\
External financing needs $_{\text {it- } 1}$ & 0.00 & 0.20 & -0.34 & 0.55 \\
Log firm age $_{\text {it }}$ & 3.69 & 1.08 & 1.10 & 5.00 \\
Log assets $_{\text {it }}$ & 13.70 & 1.63 & 10.87 & 16.98 \\
Research \& development $_{\text {it }} /$ sales $_{\text {it }}\left(\right.$ in 10 $\left.^{-2}\right)$ & 0.78 & 1.72 & 0.00 & 5.70 \\
Leverage ratio $_{\text {it }}$ & 4.08 & 5.52 & 0.33 & 20.09 \\
Family firm $_{\text {it }}$ & 0.69 & & 0.00 & 1.00 \\
\hline
\end{tabular}

The table reports the descriptive statistics of the variables used in the regression analyses. The sample includes 196 firms and 1242 firm-year observations. 
TABLE 3

Comparison of Firms With and Without NVS in 1991

\begin{tabular}{|c|c|c|c|c|c|}
\hline & \multicolumn{2}{|c|}{$\begin{array}{l}\text { Firms with NVS } \\
\quad \text { (affected) }\end{array}$} & \multicolumn{2}{|c|}{$\begin{array}{l}\text { Firms without NVS } \\
\quad \text { (unaffected) }\end{array}$} & \multirow[t]{2}{*}{$\begin{array}{l}\text { t-statistic for } \\
\text { difference }\end{array}$} \\
\hline & Mean & S.E. & Mean & S.E. & \\
\hline Industry-adjusted $\mathrm{ROA}_{\mathrm{it}}\left(10^{2}\right)$ & -0.74 & 0.38 & -0.04 & 0.41 & 1.27 \\
\hline Industry-adjusted Tobin's qit & 0.04 & 0.03 & 0.12 & 0.06 & 1.56 \\
\hline Non-voting shares it $\left(\mathrm{NVS}_{\mathrm{it}}\right)$ & 1.00 & & 0.00 & & \\
\hline External financing needs $s_{i t-1}$ & 0.03 & 0.03 & 0.02 & 0.03 & -0.31 \\
\hline Log firm age $_{\text {it }}$ & 3.94 & 0.13 & 3.32 & 0.15 & $-3.19 * *$ \\
\hline Log $_{\text {assets }}$ & 14.08 & 0.19 & 13.19 & 0.19 & $-3.23 * *$ \\
\hline Research \& development $t_{\text {it }} /$ sales $_{\text {it }}\left(10^{2}\right)$ & 0.37 & 0.15 & 0.72 & 0.21 & 1.38 \\
\hline Leverage ratio $_{\text {it }}$ & 4.50 & 0.66 & 4.43 & 0.78 & -0.07 \\
\hline Family firm & 0.70 & 0.06 & 0.82 & 0.05 & $1.66^{\dagger}$ \\
\hline
\end{tabular}

The table reports the means and the standard errors of the means of the variables used in the regression analyses of firms with and without NVS in 1991 (i.e., one year before the law change). The calculations are based on 69 firms with NVS and 66 firms without NVS. Paired sample t-test are used to compare means of affected firms to means of unaffected firms. Significance levels are denoted by ${ }^{* * *} 0.1$ percent, ${ }^{* *} 1$ percent, ${ }^{*} 5$ percent, ${ }^{\dagger} 10$ percent (two-tailed tests). 
TABLE 4

The Relationship between Dual-Class Shares and Firm Performance

Dependent variables

$\operatorname{Law}_{\text {it }}$ (=1 for firms with NVS in 1991 for

observations after 1991, =0 otherwise)

$\mathrm{NVS}_{\text {it }}$ (predicted values)

$\mathrm{NVS}_{\text {it }}$ (predicted values)* External financing needs $_{\text {it-1 }}$

External financing needs $\mathrm{s}_{\mathrm{it}-1}$

Log firm age it

Log assets ${ }_{\text {it }}$

Research \& development ${ }_{i t} /$ sales $_{\text {it }}$

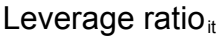

Family firm it

Firm fixed effects

Year fixed effects

Shea partial $R^{2}$ of excluded instrument

F-statistic of excluded instrument

Number of observations

Number of firms

$\mathrm{R}^{2}$ (within)

\begin{tabular}{|c|c|c|c|c|}
\hline 1 & 2 & 3 & 4 & 5 \\
\hline$N V S_{i t}$ & $\begin{array}{l}\text { Ind.-adj. } \\
\text { ROA }_{i t}\end{array}$ & $\begin{array}{l}\text { Ind.-adj. } \\
\text { Tobin's qit }\end{array}$ & $\begin{array}{l}\text { Ind.-adj. } \\
\text { ROA }_{i t}\end{array}$ & $\begin{array}{l}\text { Ind.-adj. } \\
\text { Tobin's qit }\end{array}$ \\
\hline \multirow{2}{*}{\multicolumn{5}{|c|}{$\begin{array}{c}-0.43^{* * *} \\
(0.000)\end{array}$}} \\
\hline & & & & \\
\hline & -0.21 & 0.03 & -0.18 & 0.03 \\
\hline & $(0.320)$ & (0.337) & $(0.382)$ & $(0.310)$ \\
\hline & & & $0.32^{* * *}$ & $0.02^{*}$ \\
\hline & & & $(0.000)$ & (0.033) \\
\hline 0.01 & $-0.37^{* * *}$ & -0.004 & $-0.40^{* * *}$ & -0.01 \\
\hline (0.412) & $(0.000)$ & (0.582) & $(0.000)$ & (0.449) \\
\hline 0.02 & 0.18 & -0.003 & 0.31 & 0.003 \\
\hline (0.639) & $(0.630)$ & (0.919) & (0.418) & $(0.940)$ \\
\hline 0.09 & -0.11 & $-0.25^{* *}$ & 0.01 & $-0.25^{* *}$ \\
\hline (0.198) & (0.839) & $(0.006)$ & (0.983) & (0.007) \\
\hline-0.04 & 0.16 & 0.03 & 0.13 & 0.03 \\
\hline (0.108) & $(0.422)$ & $(0.162)$ & (0.455) & $(0.170)$ \\
\hline 0.03 & $-0.68^{+}$ & -0.02 & $-0.80^{*}$ & -0.03 \\
\hline$(0.308)$ & $(0.068)$ & (0.539) & $(0.026)$ & $(0.422)$ \\
\hline$-0.04^{*}$ & 0.18 & 0.02 & 0.21 & 0.02 \\
\hline$(0.160)$ & $(0.340)$ & (0.389) & $(0.286)$ & $(0.365)$ \\
\hline yes & yes & yes & yes & yes \\
\hline yes & yes & yes & yes & yes \\
\hline \multicolumn{5}{|l|}{0.14} \\
\hline \multicolumn{5}{|l|}{$70.13^{\star * *}$} \\
\hline 1242 & 1242 & 1242 & 1242 & 1242 \\
\hline 196 & 196 & 196 & 196 & 196 \\
\hline 0.39 & 0.08 & 0.11 & 0.09 & 0.12 \\
\hline
\end{tabular}

The table reports OLS estimates of the first-stage regression in column 1 and of the second-stage regressions in columns 2 to 5 . In parentheses are $p$-values based on standard errors adjusted for heteroskedasticity (White, 1980) and firm clustering (Peterson, 2009). All variables (except binary variables) are standardized to increase the interpretabilitiy of the estimates and to reduce multicollinearity of the interaction variables. Significance levels are denoted by ${ }^{* * *} 0.1$ percent, ${ }^{* *} 1$ percent, ${ }^{*} 5$ percent, ${ }^{+} 10$ percent (two-tailed tests). 